2. Воскобойнікова Г. Л. Концепція комплексної оцінки адаптаційних можливостей у формуванні і збереженні індивідуального здоров'я людини. "Наука і освіта". 2014. №8. С. 35-39.

3. Дерека Т.Г., Туманова В.М., Бистра I.І., Гацко О.В. Оцінка адаптаційного потенціалу серцево-судинної системи студентів I курсу. Journal «ScienceRise: Pedagogical Education». 2017. №10(18). C. 13-17.

4. Леонтьєва Зоряна. Розрахунок адаптаційного потенціалу, оцінка адаптаційних можливостей організму i рівнів здоров'я студентів Львівського національного медичного університету імені Данила Галицького. Прачі НТШ Медичні науки. Оригінальні дослідження: клінічні науки . 2017. Т XLVII. C. 64-70.

5. Чернявська Л.І., Криницька І.Я., Мялюк О.П. Стан здоров'я студентів, проблеми та шляхи їх вирішення. Медсестринство. 2017. № 1. С. 24-27.

6. Чертановський П.М. Аналіз функціонального стану серцевосудинної системи у юнаків студентського віку. Проблеми фізичного виховання $і$ спорту. Педагогіка, психологія та медико-біологічні проблеми фізичного виховання і спорту. 2012. № 2. С. 128-131.

DOI https://doi.org/10.30525/978-9934-26-047-6-32

\title{
ПОРІВНЯЛЬНА ХАРАКТЕРИСТИКА СТАНУ ІНТИМА- МЕДІАЛЬНОГО КОМПЛЕКСУ ЗАГАЛЬНОЇ КАРОТИДНОЇ АРТЕРІЇ ТА ПОКАЗНИКІВ ЛІПІДОГО ОБМІНУ У ХВОРИХ З ІХС НА ТЛІ ЦУКРОВОГО ДІАБЕТУ 2-ГО ТИПУ
}

\author{
Горевич С. С.
}

аспірант кафедри пропедевтики внутрішніх хвороб

Буковинський державний медичний університет

м. Чернівиі, Україна

\author{
Скорейко Н. Т. \\ лікар-кардіолог вищої категорії \\ КП «Рівненська обласна клінічна лікарня» Рівненської обласної ради \\ м. Рівне, Украӥна
}

Серцево-судинні захворювання (СС3) $є$ основною причиною смертності хворих з цукровим діабетом (ЦД). Пацієнти 3 ЦД в середньому у 3 рази частіше страждають цереброваскулярними 
захворюваннями у порівнянні з загальною популяцією. Це пояснюється тим, що переважна кількість цих людей (75\%) помирає від причин, пов'язаних з атеросклерозом, а у $20-30 \%$ хворих з гострим коронарним синдромом діагностують ЦД [1, с. 171-179].

Для атеросклеротичного ураження притаманне формування атеросклеротичних бляшок, які переважно локалізуються в ділянці біфуркації магістральних артерій та під впливом різних етіопатогенетичних факторів мають високий тромбоемболітичний потенціал. Тому, важливим моментом, 3 точки зору профілактики кардіоваскулярних ускладнень, $є$ виявлення доклінічних стадій атеросклерозу.

Враховуючи високу розповсюдженість ЦД в популяції, а також значне підвищення ризику розвитку ССЗ в цій когорті хворих, ведення пацієнтів із СС3 на фоні ЦД 2-го типу є актуальною медико-соціальною проблемою.

Одним із основних проявів макроангіопатій у хворих на ЦД $є$ атеросклероз артерій. Його ранній початок та прогресуючий розвиток дозволяє розглядати ЦД як природну модель прискореного старіння судин та атеросклерозу. Механізми, які обумовлюють високу швидкість атерогенезу у пацієнтів з діабетом, складні, багатокомпонентні та продовжують інтенсивно досліджуватися.

Для оцінки ступеня судинного ремоделювання на сучасному етапі використовують такий показник, як товщина комплексу інтима-медіа (TIM) загальної сонної артерії, який достовірно відображає процес атеросклеротичного ураження судин і $є$ одним із ранніх маркерів субклінічного прояву атеросклерозу [2, с. 1344-1353]. Доведено, що за чутливістю та специфічностю в якості маркера атеросклерозу ТІМ переважає показники ліпідного спектру [3, с. 372-374]. ТІМ була застосована у ряді епідеміологічних та клінічних досліджень як маркер атеросклерозу i предиктор серцево-судинної захворюванності та смертності. Збільшення ТIM $є$ незалежним фактором ризику транзиторних ішемічних атак, інсульту та інфаркту міокарда [4, с. 802-808]. Збільшення ТІМ загальної сонної артерії на кожні 0,1 мм пов'язане зі збільшенням ризику розвитку IM на $11 \%$ [5, с. 1327-1334]. У діапазоні значень товщини TIM 0,61 мм частота IXC у чоловіків підвищується в 4,3 рази, а в жінок - у 9,5 разів. При показниках ТIM 0,75-0,91 мм ризик першого інсульту збільшується в 4,8 рази [6, с. $82-89]$.

Мета роботи - порівняти TIM у пацієнтів із хронічною IXC та пацієнтів із IXC, поєднаною з цукровим діабетом 2-го типу.

Значну роль у розвитку гемодинамічних порушень та судинних ускладнень у пацієнтів з ЦД відіграє ендотеліальна дисфункція (ЕД). 
Згідно з останніми літературними даними підтверджено той факт, що ендотелій є не лише внутрішньою оболонкою судин, але й важливим ендокринним органом, порушення роботи якого може спричинити розвиток багатьох захворювань, таких як ессенціальна гіпертензія, IXC та ін. Але на сьогодні все більшу увагу науковців привертає саме ЕД, яка розвивається при порушеннях обміну речовин, таких як метаболічний синдром, предіабетичні порушення вуглеводного обміну та ЦД 2-го типу. У цьому випадку ЕД вважається основним механізмом розвитку мікро- та макроангіопатій при ЦД, що також супроводжується оксидативним стресом, порушенням реологічних властивостей крові та гемостазу [7, с. 68-74]. Порушення нормальної роботи ендотелію відіграє одну з вирішальних ролей в багатьох патофізіологічних процесах, які приводять до розвитку мікросудинних уражень та атеросклеротичних змін в магістральних судинах при ЦД [8, c. 1323-1324].

Матеріали і методи дослідження. До дослідження було включено 50 пацієнтів. Усі вони були поділені на 2 групи: I група - хворі на ЦД 2-го типу у поєднанні з IXC (стабільна стенокардія напруги II-III ФК), $\mathrm{n}=25$, II група - хворі на IXC (стабільна стенокардія напруги II-III ФК) без порушень вуглеводного обміну $(\mathrm{n}=25)$. До першої групи увійшли хворі від 60 до 82 років, серед них 44\% чоловіків і 56\% жінок. Другу групу склали хворі у віці від 64 до 81 року (48\% чоловіків і 52\% жінок). Пацієнтам було проведено комплексне ультразвукове доплерогра фічне (визначення TIM) та лабораторне обстеження (у сироватці крові визначали показники ліпідного обміну). Статистична обробка отриманих результатів проводилась на персональному комп'ютері 3 використанням програми Excel.

Висновки. В результаті дослідження було встановлено, що групи пацієнтів достовірно відрізнялися між собою за рядом показників. За даними доплерографічного обстеження хворих на ЦД в поєднанні 3 IXC була більша TIM 3CA, ніж у пацієнтів з IXC без порушень вуглеводного обміну $(\mathrm{p}<0,01)$.

При дослідженні параметрів кровотоку екстракраніальних судин було виявлено, що в групі дослідження у хворих з IXC, комбінованою 3 ЦД 2-го типу були достовірно підвищені середня систолічна та діастолічна швидкості кровотоку у загальних каротидних артеріях та індекс резистентності загальних каротидних артерій (середня величина) на фоні достовірно більшої ТIM.

Таким чином, у хворих на IXC у комбінації з ЦД 2-го типу було виявлено достовірне збільшення ТIM ЗСА, що $\epsilon$ незалежним 
предиктором гострих кардіо- та цереброваскулярних подій та індексу резистентності екстракраніальних судин, показника підвищення жорсткості судинної стінки, що узгоджується з літературними даними. Що стосується бляшок у просвіті каротидних артерій, то вони були виявлені в обох групах: у I-ій групі - у 44\% пацієнтів, у II-ій групі - у $60 \%$. Найчастіше (62 \% випадків) бляшки локалізувалися в біфуркації загальної сонної артерії.

3 метою дослідження визначення впливу ЦД 2-го типу на особливості розвитку атеросклеротичного пошкодження міокарду у хворих на IXC та ЦД 2-го типу також було досліджено рівень біохімічних показників: загального холестерину (3ХC), тригліцеридів (ТГ), ліпопротеїдів високої щільності (ЛПВЩ) та ліпопротеїдів низької щільності (ЛПНЩ) у двох групах пацієнтів. У процесі дослідження виявилось, що рівні ЗХС і ЛПНЩ у хворих на ЦД 2-го типу були порівняні з такими у осіб, хворих лише на IXC. Рівень ТГ у пацієнтів 3 ЦД 2-го типу був достовірно вище $(\mathrm{p}<0,05)$ ніж у пацієнтів, що не мали ЦД. Цей результат був очікуваним, оскільки тригліцеридемія при ЦД носить вторинний характер [9, с. 1323-1331].

Специфічні зміни ліпідного обміну у пацієнтів з ЦД також супроводжувались підвищенням індексу атерогенності (IA) $(\mathrm{p}<0,05)$ у порівнянні із хворими, що не мали ЦД.

Тому можна зазначити, що хворі на IXC з супутнім ЦД 2-го типу за ліпідним спектром крові відрізнялися більш вираженою дисліпідемією атерогенного характеру від хворих на IXC без порушень вуглеводного обміну, зокрема більш вираженою тригліцеридимією ( $<0,05)$, нижчим рівнем ЛПВЩ $(\mathrm{p}<0,05)$ та вищим IA $(\mathrm{p}<0,05)$.

Отже, результати дослідження вказують на те, що наявність ЦД у хворих на хронічні форми IXC призводить до більш вираженого порушення ліпідного обміну та атеросклеротичних змін у порівнянні 3 пацієнтами з хронічною IXC без порушень вуглеводного обміну.

\section{Лiтература:}

1. Mak K.H., Moliterno D.J., Granger C.B. et al. Influence of diabetes mellitus on clinical outcome in the thrombolytic era of acute myocardial infarction. GUSTO-I. Global Utilization of Streptokinaze and Tissue Plasminogen Activator for Occluded Coronary Arteries. J. Am. Coll. Cardiology, 1997. № 30. P. 171-179.

2. Crouse J.R., Raichlen J.S., Riley W.A. et al. Intima-Media Thickness in Low-Risk Individuals With Effect of Rosuvastatin on Progression of 
Carotid Subclinical Atherosclerosis: The METEOR Trial. JAMA. 2007. № 297 (12). P. 1344-1353.

3. Djaberi R, Schuijf J, Jukema J, Rabelink T, Stokkel M, Smit J et al. Increased Carotid Intima-Media Thickness as a Predictor of the Presence and Extent of Abnormal Myocardial Perfusion in Type 2 Diabetes. Diabetes Care, 2009. № 33 (2). P. 372-374.

4. Eleid M, Lester S, Wiedenbeck T, Patel S, Appleton C, Nelson M et al. Carotid Ultrasound Identifies High Risk Subclinical Atherosclerosis in Adults with Low Framingham Risk Scores. Journal of the American Society of Echocardiography, 2010. № 23 (8). P. 802-808.

5. Feskens E.J. Glucose tolerance and the risk of cardiovascular disease: the Zutphen Study. J. Clin.Epidemiol, 2005. № 45 (11). P. 1327-1334.

6. Мітченко O.I., Корнацька А.Г., Романов В.Ю., Сопко О.В. Функція ендотелію та товщина комплексу інтима-медіа у жінок 3 метаболічним синдромом на тлі полікістозу яєчників. Український кардіологічний журнал. 2013. № 3. С. 82-89.

7. Madonna R, De Caterina R. Cellular and molecular mechanisms of vascular injury in diabetes - Part I: Pathways of vascular disease in diabetes. Vascular Pharmacology, 2011. № 54 (3-6). P. 68-74.

8. M.Avogaro A, Kreutzenberg S, Fadini G. Endothelial dysfunction: Causes and consequences in patients with diabetes mellitus. Diabetes Research and Clinical Practice, 2008. № 82 (2). P. 94-101.

9. Brannick B, Wynn A, Dagogo-Jack S. Prediabetes as a toxic environment for the initiation of microvascular and macrovascular complications. Experimental Biology and Medicine, 2016. № 241 (12). P. 1323-1331. 